\title{
From Holy Striving to Wholly Abiding: Mystical Transformation in James Hudson Taylor (1832-1905)
}

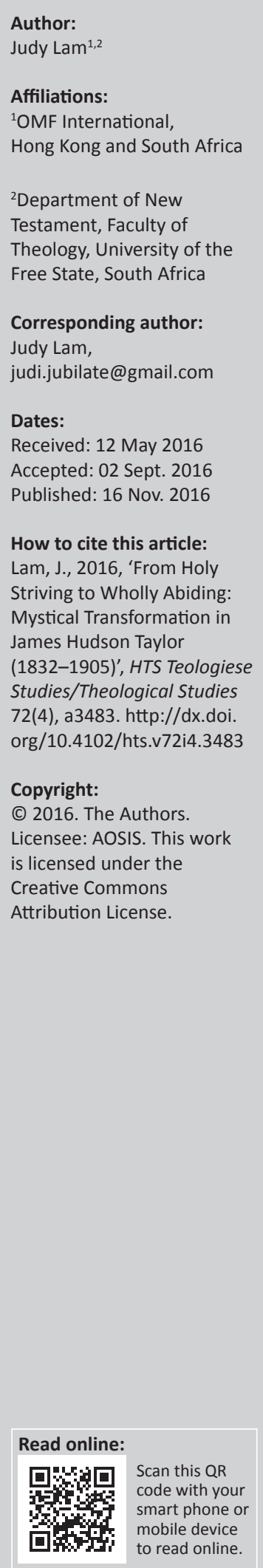

James Hudson Taylor (1832-1905), founder of the China Inland Mission in June 1865, was one of the most influential 19th century British Protestant missionaries in China. His writings, sermons and personal letters are suffused with spiritual insights and mystical nuances, notably Union and Communion, ${ }^{1}$ his short devotional work on the Song of Songs which was published in 1894. This article focuses on his mystical or transformative experience of 1869 which effected a profound experiential union with Christ and a new consciousness of soul rest. Captured here as a transformation 'from holy striving to wholly abiding', the significance of this pivotal moment is elucidated in terms of its immediate personal effect and its lasting impact on Taylor's mission vocation. The relevance of Taylor's mysticism for contemporary missionary spirituality is briefly delineated.

\section{Introduction}

The prolific writings on 'Hudson Taylor', as he is usually known, span a wide spectrum of missionary biography, devotional literature, novels, children's stories, collected works, theology, missiology, mission history, and Chinese church history. In the wealth of literature over the past 150 years, biographers of the China Inland Mission (CIM) in particular have interwoven Taylor's spiritual experiences and faith principles with his mission praxis, thereby portraying the inner and outer landscape of their charismatic leader and providing invaluable insight into a 19th century pioneer missionary in China. Little in-depth research, however, has been conducted on the topic of 'the spirituality of Hudson Taylor,', not to mention the eclipse of his mystical dimension by his missionary endeavours. While Taylor's experience of 1869 does not go unmentioned in writings on his spiritual life, ${ }^{3}$ few authors describe it as mystical transformation which the present article articulates as 'from holy striving to wholly abiding'. By identifying this 'holy moment' as the apex of Taylor's spiritual journey and elaborating the profound effect on his personal life, missionary vocation, and love for the Song of Songs, it will become evident that Taylor's mysticism is the raison d'etre for his spiritual legacy and a treasure trove for contemporary spirituality studies. Several suggestions are delineated for a rediscovery of Taylor as a mystic and a critical reconsideration of his model of a holy life for contemporary Protestant missionary spirituality.

\section{Definitions and scope}

It is helpful to state at the outset that this article represents an initial attempt to explore Taylor through the lens of the (academic) discipline of Spirituality, ${ }^{4}$ and forms part of my ongoing research as a spiritual director and missionary. Several definitions are delineated at this point, which will underpin the mosaic of historical detail and provide contemporary perspectives on Taylor's (19th century) mystical transformation. Firstly, Schneiders defines spirituality as 'the experience of conscious involvement in the project of life-integration through self-transcendence toward the horizon of ultimate value one perceives' (2011:16); and, with reference to Christian Spirituality, it specifies the horizon of ultimate value as 'the triune God revealed in Jesus Christ ...' (2011:17). Schneiders clarifies that spirituality is 'a conscious and deliberate way of living' and 'an ongoing project', not simply 'a spontaneous experience' (2011:16). Integral to her definition is attention to the human subject as a whole person within the multiplex dynamics of lived experience. Secondly, acknowledging that 'spirituality' is a broader term than 'mysticism'

\footnotetext{
1.The full text of Union and Communion is available online: http://www.ccel.org/ccel/taylor_jh/union.html
}

2.Wigram's chapter on 'The Bible in J. Hudson Taylor's Spirituality' (2007:79-115) includes a sub-section entitled 'Spirituality'; the characteristics include Self-surrender to God, Perfect Holiness, Entire Consecration, Higher Plane, Consolations of Christ, and Praise and Glory to God (2007:89-100).

3.For example, Wigram comments on Taylor's spiritual experience of 1869 in relation to his emphasis on resting and abiding in Christ (2007:100-113); and also highlights mystical elements in Taylor's life, mission, and holiness teaching (2007:244).

4.This article is a reshaping of my paper read at the Holiness Conference in Johannesburg (May 20-23, 2015), convened by the Spirituality Association of South Africa (SPIRASA) and the Society of the Study of Christian Spirituality (SSCS). 
although closely related (Kourie 1981:72), the scope of this article will be confined to Christian Spirituality and 'Christian mysticism' or, 'Christ-mysticism' (Kourie 1981), where the latter is defined as 'consciousness of union with the Divine, or the Ground of Being, or Ultimate Reality' (Kourie 1981:71). To delineate the varieties of type, the complexities of nuances and the perplexities of prejudice aroused by the word 'mysticism' is beyond the present scope - a subject which is admirably addressed by contemporary scholars. ${ }^{5}$ Thirdly, Kourie's definition of mystical transformation is apt given her emphasis on 'a mystical lens' to reading scripture which is transformative (2012:2), as follows:

mystical transformation leads us beyond limited and onedimensional forms of consciousness, resulting in an enhanced attentiveness to reality and a new theocentric perception, the psychotherapeutic value of which can be seen in an increased zest for life and selfless service of others. (Kourie 2012:1)

Fourthly, the authenticity of personal transformation as it impacts the totality of the mystic's life, including the missional, is a defining factor in mysticism, as noted in McGinn's assertion:

the only test that Christianity has known for determining the authenticity of a mystic and her or his message has been that of personal transformation, both on the mystic's part and especially - on the part of those whom the mystic has affected. (McGinn 2006:xvii)

\section{Early formation of Taylor's mystical sensitivity}

Born in Barnsley, Yorkshire, on 21 May 1832, into a pious Methodist home, the religious fervour of his parents and their prayerful interest in China implanted in their first born the seed of foreign missions. Feeble health in childhood instilled in Taylor a sense that his life was not his own; and thus, from an early age, he professed 'a genuine desire for holiness' (Wigram 2007:91). ${ }^{6}$ In 1849, aged 17, he experienced a radical conversion when the efficacy of the words the finished work of Christ' brought a 'joyful conviction ... as light was flashed into [his] soul by the Holy Spirit' (Pollock [1962]/1996:12-13). A year later, he responded in radical obedience to the divine presence which 'took possession' of him, effecting 'unreserved consecration', a 'very practical consciousness' and an overwhelming assurance of a divine call to China (Broomhall 1929:7-8). In both instances, the young Taylor was 'alone with the Alone' - encountering the mysterium tremendum and confronting his own sinfulness and deeper self.

At different levels, these early experiences may be regarded as kataphatic in terms of the felt presence of the immanent God. They were also mystical, by virtue of divine bestowal, which effected an experiential and transforming knowledge of the 'finished work' of the Risen Christ, an infusion of joy and illumination by the Spirit; and the second, a new consciousness

\footnotetext{
5.Kourie's writings, as one example, are especially helpful on the academic, . with an overarching emphasis on human transformation (1981, 1998, 2012, 2015).

6.Wigram's work (2007) delineates the religious influences on Taylor's pursuit of holiness.
}

of call, consecration and possession by God. These particular moments of encounter with the Other translated into practical steps for living his entire life 'in the mysterium called God' which, according to Perrin, is the goal of Christian mysticism (2007:241). The affirmation of his faith, his deep humility and reverential awe, and the consciousness of the presence of God were characteristic of his prayer life and personal correspondence with family members. His 'practical consciousness' translated into radical faith in God alone and a joyous development of extreme self-designed disciplines and ascetic practices. Holiness and humility were embodied in simple lifestyle, voluntary preparation for China, efforts to learn the Chinese language, identification with the poor, initial medical training, and courageous commitment to a missionary vocation. This formation in holiness and humility was an effective component of Taylor's spirituality, in light of Waaijman's explication of the Greek word askesis, which means 'exercise': it is 'a deliberate human effort' or 'a deliberate methodical effort of a human being' which touches upon the entire complex of a person's life and 'all the facets of the spiritual way' (2002:338, 342). In sum, prior to leaving England, Taylor's spirituality as a youth was shaped experientially by a practical faith, rigorous self-discipline and experiments in asceticism - and is thus described as holy striving.

\section{Transformation from holy striving to wholly abiding}

From his arrival on 01 March 1854, not quite 22 years old, Taylor was plunged into the dark sides of missionary life and was forced by circumstances to fight for survival. The inner forces of loneliness, hunger, embarrassment over lack of funds and sleepless nights, as well as the external dangers of war in the mercantile city of Shanghai, purged his romantic view of missions. Nevertheless, Taylor's earlier mystical experiences and spiritual formation enabled him to develop radical trust in God to provide for all his needs - through prayer alone, and not by solicitation of funds. Facing the unknown and unfamiliar through holy striving sensitised him to the presence of God in mundane matters and in extraordinary lifethreatening events, drawing him into a closer identification with Jesus' 'holy, self-denying love', and giving grace to endure suffering and value his call to China (Pollock [1962] 1996:69). Moreover, he began to transform socially and culturally by rejecting the missionary status quo with the courage and intensity of a maverick. Unlike few Protestants of his time, Taylor 'was prepared to sink his European self in identification with Chinese people' ([1962] 1996:40-41), chose to reside among the crowded native population and opted for Chinese dress for the sake of easier access to the mainly peasant population. In 1855, he changed his Western hairstyle to a pigtail, despite personal criticism by and embarrassment to the missionary establishment.

The disposition of holy striving is discernible in the intense purgation wrought after falling in love with Maria Dyer in Ningbo - a crucial moment when the Song of Songs served as a catharsis during adversity and hostility. As Maria was a missionary orphan at the time and a refined young 
woman, Miss Aldersey, her 'protector', reacted vehemently to 'Mr Taylor' whom she considered a 'young, poor, unconnected Nobody!'; 'without education and without position'; and 'not a gentleman' (Pollock [1962] 1996:80). The controversy over Hudson and Maria's engagement erupted in 'flames of dispute, of defence and attack ... to the astonishment of the Chinese'; significantly, it was in the heat of the onslaught that the young lovers took refuge in the Song of Songs ([1962] 1996:83). Maria expressly desired that 'Jesus may be to me the chiefest among ten thousand, the altogether lovely' ([1962] 1996:83); meanwhile, Hudson found in the Song 'a rich garden to delight in', understanding in new ways divine love and 'the love of Jesus to His redeemed' (Taylor \& Taylor 1965:134-135).

The romantic 25-year-old Hudson's 'warm-blooded yearning to love and be loved' (Pollock [1962] 1996:98) was satiated by his marriage to 21-year-old Maria on 20 January 1858; and, as an oblique reference to his vibrant sexuality, Barr comments, Maria was 'almost constantly pregnant because of Hudson's passionate adoration of her' (1972:48-49). Spiritually sensitive and linguistically gifted, Maria matured and refined Taylor on many levels. The downside to Taylor's holy striving however was his tendency to overwork, given the increasing demands of medical work, evangelistic ministry and souls dying daily without Christ. Failing health and the need to recruit more workers necessitated a voyage back to England (July 1860), ${ }^{7}$ ushering in an important period of physical recovery and spiritual discovery (November 1860-May 1866). It was during this 'downtime' - a period called the 'hidden years' in the biography - that the CIM was born, following Taylor's momentous realisation on Brighton Beach (25 June 1865) that the overwhelming responsibility of mission was God's, not his. His response of radical surrender to the divine Other effected Taylor's unprecedented decision to found an inland mission in China, at this low point of his life, without financial resources and without denominational backing. Following Kourie's description of the mysticism of the Beatitudes as kenotic (2012:9), when Taylor's momentous decision is viewed in terms of 'kenosis', which effects happiness and blessedness in the poor in spirit, it is significant that the CIM was birthed in the paradox of emptiness and fullness. This in itself is an important tenet in mysticism.

Blessedness through kenosis was characteristic of Taylor's holy striving - and his leadership of a fledgling mission. Dubbed the 'Pigtail Mission' (Chang et al. 2005:48) on the arrival of the new CIM missionaries in Shanghai in $1866,{ }^{8}$ they withstood ridicule and criticism, insisted on close identification with the mainly poor Chinese populace, opposed Western imperialism, maintained a strong ethos on contextualisation of the Gospel and were committed to the Christianisation of the Chinese people (Chang et al. 2005: 174-175). ${ }^{9}$ Faith in God alone was an overarching principle,

\footnotetext{
7.On the Taylors' first voyage to England in July 1860, Wang Laijun accompanied them to assist in the translation of the New Testament, a hymnbook and tracts in the Ningbo dialect. Taylor completed his medical training in England, and qualified for Licentiate in Midwifery (May 1861-July 1862), as noted in Chang et al. (2005:36-38).

8.The Lammermuir Party comprised Hudson and Maria Taylor, their 4 children, and 16 missionaries with little formal education.

9.'Nowhere was the unholy alliance between the Gospel and gunboat closer than in China' (Kane 1994:200).
}

along with courageous sacrifice and the acceptance of martyrdom for the sake of Christ, even if it meant foregoing consular protection by foreign governments in the midst of anti-foreign attacks. Guided by this higher motive, the CIM chose to embody the counter-cultural compassion of Jesus by not seeking revenge for false accusations against them and refusing to make demands for compensation when mistreated by Chinese rebels. The Yangzhou Riot of $1868^{10}$ is a case in point. In fact, the Riot sparked such political reaction in the House of Lords that discussion was held on whether to order all missionaries to leave China in order to avoid the disruption of trade. Furthermore, vicious attacks by the British press caused bad publicity for the CIM and a significant drop in financial support (Chang et al. 2005:52-53).

In terms of the circumstances and context for the preparation of divine intervention and mystical transformation, it was at this juncture in the aftermath of the Yangzhou Riot that Taylor's momentous experience occurred - in 1869, at the age of 37. Described in nuce as a transformation from holy striving to wholly abiding, it represents the apex of his spiritual life - a unitive experience which was marked by a transforming union in Christ. Referred to as 'The Exchanged Life' in the official biography (Taylor \& Taylor 1965:204), ${ }^{11}$ it is evident that Taylor's physical and mental condition, and despair and dissatisfaction of his spiritual condition, catapulted his desire for holiness and a deeper way with God. Often sick in body; perplexed by conflicts, rumours and criticism; close to breaking point; and 'working without precedent in many respects', he was faced with 'the awful temptation ... even to end his own life'; in fact, it was Maria 'who stood between him and suicide' (Pollock [1962] 1996:192-195).

Recalling Kourie's definition on mystical transformation previously mentioned, what follows is Taylor's 'enhanced attentiveness to reality and a new theocentric perception'. Synchronous to Taylor's experience was the topic of holiness which featured prominently in England the year before, in the columns of Christian literature (Broomhall 1929:156). Popular teachings on sanctification brought the subject of a deeper spiritual life to the CIM, including Taylor himself (Wigram 2007:92-93), enabling a transparency and vulnerability in sharing his spiritual agony. After several days of praying and striving for 'oneness with Jesus' and searching for a way to enjoy deeper fellowship with God Taylor discovered the joy of 'abiding, not striving or struggling', and of 'resting in the loved one entirely' ([1962] 1996:196-197). His mystical experience is underscored by Perrin's understanding of 'the core of mysticism' as 'the radical surrender of self to the loving embrace of the Other who is at the foundation of all life, the One to whom we owe our very existence' (2011:443). A new consciousness flowing from experiential union is expressed as 'I am one with Christ'; and the experiential reality of the indwelling divine presence is expressed as ' $\mathrm{He}$ is mine, and is with me ... and now Christ lives in me' (Taylor \& Taylor 1965:212-215). The transformation

10.Maria, 6 months pregnant, needed to jump from the second floor to escape. The birth of Charles Edward Taylor 10 days after their return to Yangzhou is evidence of the Taylors' courageous love and forgiveness (Chang et al. 2005:51).

11.For further reading on the significance of this experience in Taylor's spirituality, see Wigram (2007:107-111). 
effected an exuberance that could not be contained, as Taylor exclaimed to his fellow workers that night: 'God has made me a new man' through the light of 'the blessed Spirit poured direct into my soul!' (1965:212-215). A historian refers to that day as 'The Pentecost of Hudson Taylor and the CIM' (Chang et al. 2005:53). The profound infusion of fully resting and wholly abiding in the loved one - 'ever active yet ever at rest' - enabled Taylor to lead the expanding CIM for another three decades, until November $1902 .{ }^{12}$

\section{Mystical impact on personal life and message}

Perrin's emphasis on 'living in the mysterium' is underscored by Kourie's elaboration of mysticism as a 'way of life, in which the purifying, illuminating and transforming power of God is experienced, effecting a transmutation of the mystic's entire being and consciousness' (1981:72). Several aspects are delineated to demonstrate Taylor's transformation as it effected a way of living in the mysterium, or a mystical way of being and doing.

\section{Increased zest for life and selfless service for others}

Taylor's new-found oneness with Christ was evident also in a deeper union with Maria, reflecting the embodied union of divine and human love. Moreover, the new consciousness of fully resting and wholly abiding in love sensitised him ever more deeply to the divine presence and sustained him in even darker hours of crisis, suffering and grief than the Yangzhou Riot, namely: as the elder children left China to study in England, the sudden sickness and death of young Samuel just before sailing (Broomhall 1929:151-152), Maria's deteriorating health due to cholera, the death of their fifth son Noel when he was only 13 days old, followed by Maria's courageous death at the age of 33 after 12 harmonious years of marriage. ${ }^{13}$ Barr states that from this point on, the 'spiritual intensity of the medieval mystic burns through much of Taylor's writing' (1972:49) - a flame that blazed also in his marriage to Jennie Faulding on 28 November 1871 - a close friend to Hudson and Maria and one of the first CIM workers in Hangzhou.

Despite frequent bouts of serious illness, Taylor's 'zest for life and selfless service for others' increased for the glory of God. From November 1874 to April 1875, aged 43, he led the mission from his bed, praying for new workers for China, and began writing the CIM's first issue of China's Millions in July (Chang et al. 2005:61). His personal sacrifice and 'obedience to the heavenly vision' resulted in prolonged periods of separation between husband and wife, and parents and children. ${ }^{14}$ During the Great Famine of 1876-1879, for example, Jennie returned to China to

12.D.E. Hoste succeeded Taylor as director of the Cim in January 1903 (Chang et al. 2005:115).

13.It is correctly said that 'without Maria, Taylor never could have embarked on his life's work' (Pollock [1962] 1996:98-99).

14.Thompson reports that when Taylor returned home after 16 months away on travels in China, Christmas 1877, 'his two youngest children did not even remember him' (1982:57). The support of extended family was crucial. Taylor's sister, Amelia Broomhall, took care of Jennie and Maria's children, besides her own 10 when Jennie returned to China to assist in famine relief. assist with famine relief and orphanage work, leaving behind her husband, their 3-year-old Ernest and 18-monthold Amy (Chang et al. 2005:67). As one of the first CIM women to travel inland, Jennie became a missionary pioneer in her own right; three years, however, had passed before she saw her children again (Thompson 1982:61).

Taylor found solace in the Song of Songs during long separations from Jennie (Wigram 2007:56) - a practice which evidently enriched his sexuality and deepened his spirituality. As an avid correspondent - in 1888, just before sailing to North America - he expressed to Jennie his desire that their whole life 'be an ascending plane', a 'pressing on and up', a gazing on God and grasping more of the heights and depths of God's character and purposes (Taylor \& Taylor 1965:305). From May 1891, over the span of one year, Taylor wrote a series of reflections on the 'Song of Solomon' in China's Millions - an influential missionary magazine of the CIM which he personally edited. These were later published in book form with the apt title of Union and Communion.

\section{Spiritual marriage and radical integrity}

The indwelling presence of God as divine love, life and light effected an integrity of being and doing in his missionary spirituality: 'because we are His, and one with Him whose work it is' (Taylor \& Taylor 1965:216-217). This mystical way of life was also expressed in terms of spiritual marriage: 'To know Christ as the Bridegroom is most blessed; to be not betrothed and having occasional visits, but married' (Taylor \& Taylor 1965:257). It is stated elsewhere that Taylor lived as though 'married to another', suggesting that his spirituality was selftranscending, not self-serving. With reference to Schneider's definition of spirituality as a 'conscious involvement in the project of life-integration through self-transcendence', it is noteworthy that Taylor is acutely aware of the excesses or misconceptions of soul rest. For example, hindrances to unrestrained communion with God include 'slothful selfindulgence' and 'spiritual pride' (Taylor [1894]/2006:87-89); and he employs missionary language to the Song to challenge self-preoccupation and unhealthy passivity: to not 'delight in the rest of faith while forgetful to fight the good fight of faith' ([1894]/2006:87-89). By implication, in the radical integration of mysticism and mission, self-transcendence is characterised by conscious self-giving, as follows: 'self-denying efforts to rescue the perishing' rather than 'self-satisfaction and love of ease' (Taylor [1894] 2006:87-89). The lack of conscious involvement in one's spirituality as an ongoing project therefore results in neglect, lethargy and complacency -- even spiritual desolation.

\section{Prophetic and authentic}

Taylor's authentic transformation and 'conscious and deliberate way of living' led to unconventional ideas and controversial decisions, defying the status quo in spite of opposition, criticism, persecution and martyrdom. One example was the CIM's acceptance of women as missionaries in their own right - a courageous and necessary innovation that served as a counter-cultural impetus on both the Western (Victorian) and Chinese (Confucian) front. Taylor, however, 
was severely criticised as follows: 'The most eccentric missionaries are naturally those, many of them single women, belonging to Mr Hudson Taylor's CIM' (cited by Wigram 2007:208-211). Yet, in spite of prevailing attitudes, women comprised nearly half of the missionary force in China during 1885-1900 (Barr 1972:127). Married and single, they went on to make a significant contribution to Protestant missions in China and to facilitate change in the perceptions and politics of formal education for Chinese women.

An extraordinary test of Taylor's authentic spirituality was his response to the xenophobic Boxer Uprising in 1900, where the CIM lost 58 missionaries and 21 of their children at the hands of the Boxers (Barr 1972:195). ${ }^{15}$ Kane states that 'Nowhere was Taylor's generous spirit more clearly seen than in his handling of the Boxer indemnities' (1994:199). While convalescing in Switzerland at the time, Taylor's wholly abiding in God best describes his state of helplessness as the news of devastating proportions unfolded: 'I cannot read; I cannot think; I cannot even pray; but I can trust' (Chang et al. 2005:115). The decision that the CIM would neither claim nor accept any compensation from the Chinese authorities, even if offered, was a living testament to the depth and generosity of divine love (agape).

\section{Humility in a culture of veneration}

Given Taylor's depth of humility, it is important to note that it grieved him when people referred to him as a 'great leader' (Kane 1994:199-200). Taylor did not seek 'to build an empire or to make a name for himself', but his overriding ambition was 'to be well pleasing to God' (Kane 1994:199) - a recurrent theme in Union and Communion. Yet, by the time of his death in 1905, the CIM was described as 'an international octopus' with 800 men and women at 60 stations in 15 out of 18 provinces of China - constituting one-quarter of the entire Protestant mission force in China' (Austin 2007:xxiv). Taylor's missionary legacy has continued uninterruptedly for over 150 years with four generations succeeding him in Chinese ministries. After the CIM's 'reluctant exodus' from China (1949-1953) and the extension of its ministry to other Asian countries, the organisation changed its name to the Overseas Missionary Fellowship (OMF), and more recently to OMF International. ${ }^{16}$ The empowering and unquenchable Spirit enables OMF's over 1400 members (from over 40 nations) to serve among 100 people groups in East Asia, and among the Asian diaspora around the globe (Dowsett \& Berry 2014:338).

With an exemplary spirituality and extraordinary missionary legacy, it is understandable that the name 'James Hudson Taylor' (戴德生) commands respect to this day and continues to endear the hearts of Chinese people, as Doyle correctly observes: 'Anyone who has served among the Chinese

15.The death toll of CiM missionaries in the Boxer Rebellion was "by far the highest of all the Protestant societies', yet the CIM 'gained the greatest number of recruits the
very next year' (Barr 1972:195). See Barr's chapters on 'The Blood of the Martyrs' very next year' (Barr 1972:195). See Barr's chapters on 'The Blood of the Martyrs'
and 'Miles of Miracle' which reflect the harrowing experiences of missionaries during the Boxer Rebellion.

16.For online access, see www.omf.org; and for a brief overview of OMF's history, see Dowsett and Berry (2014). knows how the name "Dai Desheng" brings expressions of admiration, even reverence' (2015b:121). The aura of sanctity, however, surrounding 'the Venerable Preacher' (2015b:115) is often misconstrued as hagiography. In this regard, Stanley's comments are pointed, that Taylor's secured place in 'evangelical hagiography' is partly due to the portrayal of him in the literature as symbol of 'the perfect union' of 'mystic as well as missionary' (in the foreword to Austin 2007:xiii-xiv). ${ }^{17}$

From the perspective of mystical transformation, the 'transmutation of the mystic's entire being and consciousness' does not diminish humanity; rather, it effects a deeper engagement, a graced presence and a more fully human way of being in the world. In union with the Source, the mystic facilitates an awareness of the divine in all of reality. In Taylor's case, the most populous nation on the face of the earth provided a complex acculturation in an ancient culture of Confucian or Buddhist or Taoist socio-religious interfacing, at a time of unequal treaties and conflictual political wrangling between foreign powers and Chinese authorities, when China was relatively poor and invaded by 'foreign devils', etcetra. Against this backdrop, China was a gift to Taylor's 'conscious involvement in the project of life-integration through selftranscendence' across a span of 50 years. It begs the question: 'Who or what would Hudson Taylor have become without China?'

\section{'The Loyola of Protestant Missions'}

Compatriot Dr W.A.P. Martin ${ }^{18}$ - the respected American Presbyterian scholar on Chinese culture - describes Taylor in his early years as 'meandering around China without denomination or settled purpose' - a 'mystic absorbed in religious dreams, waiting to have his work revealed' (Pollock [1962] 1996:75). Taylor's humility and maturity impressed Martin to the extent that he cited Hudson Taylor as 'the Loyola of Protestant Missions' - a 'true mystic' who was 'most practical', one of those people 'who see and experience more vividly a Reality which there is for us all' (Broomhall 1929:186). Ignatius of Loyola (1491-1556), by way of background, was an innovative mystic in terms of the laity; and it was the Jesuits who introduced the term 'missions' for the first time 'in connection with overseas ministries' (Wigram 2007:21). With reference to Reilly's work entitled Spirituality for Mission (1978:75-77), the Society of Jesus founded by Ignatius was 'the foremost missionary sending group in the Catholic Church' in the 16th-19th century; missionary service was viewed as 'the highest expression of the Jesuit vocation'; at the heart of the Jesuit apostolate is union with God, enthusiasm for Christ, personal holiness and finding God in all things, and a characteristic of Jesuit spirituality is 'contemplation in action'. Ignatius, however,

17.Austin's work (2007) has received mixed responses: Doyle (2015b:115) comments on the author's 'acerbic treatments of Taylor', while Wigram (2007:15) suggests his purpose is 'to shift the focus away from Taylor onto other factors'.

18.According to Covell (1986:102), Martin read extensively on the work of the Jesuits in China during the Ming dynasty, and 'liked to think of himself as a Protestant Mattheo Ricci'. By way of background, Matteo Ricci obtained permanent residence near Canton in 1583, reached Peking in 1601, and his death in 1610 brought an end to the first period of the Jesuit mission to China (Latourette 1929:92-97). 
is not normally associated with the Song of Songs and bridal mysticism; hence, Taylor is better understood through a wider lens, as elucidated in the next section.

\section{Union and Communion as mystical text}

The word mystical $^{19}$ is particularly important in relation to the Song of Songs which, for Jewish and Christian mystics alike, was 'the mystical book par excellence' (McGinn 2006:4). Taylor's affinity with the Song of Songs became an embodied mysticism in his missionary vocation. The first official biographers of the CIM, Howard Taylor and Geraldine Taylor (son and daughter-in-law who also served with him in China), described their father in later years as follows: 'nothing was more characteristic than his love for the Song of Solomon and the way in which it expressed his personal relationship to the Lord' (1965:134). At aged 60, amidst the pressures of mission leadership, administration of funds, etc., and on a visit to Australia, Taylor was described by his host as being 'in God all the time, and God in him', reflective of 'the "true abiding" of John 15' (1965:316-317). ${ }^{20}$ The symbol of the True Vine in John 15 was a favourite text, alongside the Song of Songs, to explicate the pure rest, holy living and increasing fruitfulness effected by abiding in Christ (Taylor [1894]/2006:64). These texts resonate with McGinn's insights on the use of the word 'union' in the mystical tradition - that it was 'fundamentally Christological' and implied 'becoming one with Christ', based on the metaphor of being 'engrafted into Christ' (Jn 15), the Pauline motif of being 'in Christ' and the model of sexual union found in the mystical reading of the Song of Songs' (2012:32).

Union and Communion is undoubtedly an encapsulation of Taylor's mysticism, particularly his affinity with the bride and bridegroom relationship of the Song of Songs. Taylor's teaching on the Song of Songs though includes missionary motifs; for example, devotion to Christ the Bridegroom called for a response to the bridegroom's gracious initiative, which was hampered only by neglect or disobedience on the part of the individual Christian (Wigram 2007:153). At international conferences, including the Keswick Convention, Taylor became 'a catalyst for the link between holiness teaching and mission' (Wigram 2007:92-93). In sum, as mystic and missionary, Taylor's message pivots on the love of God and reflects a radical integration of the Song of Songs and the Great Commission.

\section{Relevance for contemporary missionary spirituality}

Wigram comments that Taylor's 'distinctive hermeneutic and example shaped the collective spirituality of the CIM which eventually became a template for subsequent expression of

19.The adjective mystical, meaning "hidden' in Greek, refers to "the inner sense of the Bible', while 'mystical contemplation' is essentially 'knowledge of God gained by the soul's direct reception of a divine gift' (McGinn 2006:3-5).

20.The True Vine as core symbol of Christian mysticism, in relation to the vineyard metaphor in the Song of Songs, is explored in Chapter 5 of The Canticle of Spiritual Direction: A Transformative Approach to the Song of Songs. http://uir.unisa.ac.za/ handle/10500/8103 mission in the conservative evangelical tradition' (2007:6). Therefore, the question of relevance for contemporary missionary spirituality is important in terms of holiness, which, as previously stated, is an effect of living 'in the mysterium'. A footnote by the anthropologist Hiebert caught my attention: 'In Protestantism, the Christian model is the scholar. ${ }^{21}$ Little is written about 'saints' or 'holy people'. ... As Protestants we need to rediscover the importance of saintliness and models of holy living' (2008:295). ${ }^{22}$ On the substantiation of this article, it is fitting that Hudson Taylor be recognised as an exemplary mystic of the church which will augment the respect accorded him as 'one of the greatest missionaries that the Church has known' (Latourette 1929:259).

What would be the benefit in terms of Hiebert's rediscovery of 'holy people' or 'models of holy living?' Mystical transformation from 'holy striving to wholly abiding' is a poignant illustration of the in-breaking of God at critical junctures of life, especially at midlife and beyond. Taylor's experience at the age of 37 was evidently a 'salvific' and 'kairotic' moment when the divine initiative rescued him from the abyss of despair - the outcome being the grace of an 'Exchanged Life'. This suggests a model of holiness or saintliness that is not founded on stoicism, idealism, perfectionism or heroism, but on human brokenness transformed into the beauty, blessedness and bliss of being a bride of the divine Beloved. For this precise reason, aspects of his holiness teaching from the Song of Songs are pertinent as follows: 'take time to be holy'; avoid 'the mistake, the sin, of not keeping our own vineyard'; be aware of the danger of 'intense activity' which may lead to 'zeal in service, to the neglect of personal communion'; and 'if we are watchful over the souls of others, and neglect our own', our powerlessness will disappoint (Taylor [1894]/2006:68-69). While Taylor does not refer explicitly to his own foibles and failures in Union and Communion, it is presupposed from historical detail (gleaned from his other writings and from biographies) that his insights on holiness are distilled from his lived experience. Taylor's authentic transformation 'from holy striving to wholly abiding' therefore speaks profoundly to the contemporary overemphasis on skills and doing, often to the neglect of being-in-love. His contemplative abiding and non-egoistic motivation also counteract the allure of compensatory activism and seductive heroism in missionary service. Furthermore, written by 'an old hand' with East-West missionary experience in a primarily Confucian or patriarchal Chinese culture, Taylor's depth of intimacy and vulnerability adds a mystical poetic to the intercultural conversation.

In terms of the relevance for contemporary missionary spirituality, the biblical injunction to 'remember', 'consider' and 'imitate' your leaders (Heb. 13:7) is pertinent to the

21.For renowned Protestant missionaries/scholars of the 19th century China context see Mission Legacies (Anderson 1994); Confucius, the Buddha, and Christ (Covell 1986); and Builders of the Chinese Church (Doyle 2015a), among others.

22. Hiebert notes that the New Testament (including Eph. 1:1; Phil 1:1; Col 1:2) refers to Christians as saints some 50 times and elaborates the affirmation that God is holy and creation is also to be holy (2008:295-298). 
Protestant missionary community. By remembering Taylor as a mystic, we recall our oneness with Christ, re-member the disparate parts in ourselves, and recollect our at-one-ness in Christ. Union thus implies being at home with the indwelling God - an 'at-home-ness' where home becomes the place of contemplation (Waaijman 2002:69). This critical rediscovery of the inner life is imperative if Bebbington's critique is to be taken seriously:

the inward life, especially in the evangelical tradition, has not received the attention it deserves, in spite of the fact that holiness was a major theme in the roots of the spirituality. (cited by Wigram 2007:3-4)

In remembering Taylor, cognisance is taken of Wigram's comment that 'the line between myth, hagiography and reality are not always easy to discern' (2007:17). Taylor was not without contradiction; and the CIM in its day had its critics, especially with regard to its narrow theology and antiquated methods of evangelism (Latourette 1929:384). Contemporary critique of 19th century pioneering mission praxis and its negative impact on family life, for example, is being given a voice (Doyle 2015b). Further interdisciplinary reflection will be necessary for questions of holiness/wholeness from a psychospiritual perspective (care of body and soul), and on issues of intercultural dynamics and interreligious conversation.

\section{Conclusion}

The elucidation of Taylor's mystical transformation centres on his 1869 experience as the apex of his spiritual life - a pivotal moment that occurred while he was 'in motion' holy striving almost to breaking point - when the divine in-breaking effected a self-transcending consciousness of wholly abiding and fully resting in divine love. Living 'in the mysterium', transformation became a way of life for Taylor; he was constantly in process, adapting to change, making unprecedented decisions, and wrestling with the uncertainties, perplexities, ambiguities, and complexities of a zealous 19th century pioneer missionary in China. This article therefore posits that mystical transformation was the raison d'etre for Taylor's intense union and communion with God - a divine-human intimacy that enabled him to find spiritual heights and depths in his lived experience, web of relationships, and East-West missionary vocation. Moreover, based on pertinent citations by Taylor's contemporaries, and identifying his Union and Communion as a mystical text, this article has substantiated the value of Taylor's mysticism for contemporary missionary spirituality. Given the growing interest in spirituality and mysticism in these early decades of the 21st century, ${ }^{23}$ coupled with the resurgence of studies in the Song of Songs, ${ }^{24}$ the ground is fecund for the recovery of Taylor's mysticism. Within the Protestant evangelical

23. Kourie's article on "Weaving colourful threads: A tapestry of spirituality and mysticism' (2015) discusses the diverse strands and contemporary issues, and concludes with the meaning and significance that spirituality and mysticism bring to lived reality in the 21 st century.

24.Lam (2015) offers 'a spiritual direction lens to reading the Song of Songs' by incorporating Spirituality's focus on the spiritual life as experience, new ways of reading scripture, interdisciplinary studies, etc. community, critical reconsideration of Hudson Taylor as a Christian mystic would render mysticism applicable to the 'ordinary saint' and accessible to 'the priesthood of all believers'.

\section{Acknowledgements Competing interests}

The author declares that she has no financial or personal relationships which may have inappropriately influenced her in writing this article.

\section{References}

Anderson, G.H. (ed.), 1994, Mission Legacies, Orbis, Maryknoll, NY.

Austin, A., 2007, China's millions: The China Inland mission and late Qing society, 1832-1905, William B. Eerdmans Pub, Grand Rapids, MI.

Barr, P., 1972, To China with love, Secker and Warburg, London.

Broomhall, M., 1929, Hudson Taylor, the man who believed God, China Inland Mission, Philadelphia, PA.

Chang, I., Taylor, J.H. III, Taylor, J.H. IV, Wu, J., Yiu, J., Yu, L., et al. (eds.), 2005, Christ alone: A pictorial representation of Hudson Taylor's life and legacy, OMF International, Hong Kong.

Covell, R.R., 1986, Confucius, the Buddha, and Christ: A history of the Gospel in Chinese, Orbis Books, Maryknoll, NY.

Dowsett, R. \& Berry, C., 2014, God's faithfulness: Stories from the China Inland Mission and OMF International, OMF International, Singapore.

Doyle, G.W. (ed.), 2015a, Builders of the Chinese Church: Pioneer Protestant Missionaries and Chinese Church Leaders, Pickwick Publications, Eugene, OR.

Doyle, G.W. (ed.), 2015b, 'J. Hudson Taylor: Advocate for China's Inland Millions', in Builders of the Chinese Church: Pioneer Protestant Missionaries and Chinese Church Leaders, pp. 101-121.

Hiebert, P.G., 2008, Transforming worldviews, Baker Academic, Grand Rapids, MI.

Holder, A. (ed.), 2011, The Blackwell companion to Christian Spirituality, Wiley, West Sussex.

Kane, H., 1994, 'J. Hudson Taylor', in G.H. Anderson (ed.), Mission legacies. Mission legacies, pp. 197-204, Orbis, Maryknoll, NY.

Kourie, C., 1981, 'Christ-Mysticism in Paul?', Theologia Evangelica 14(3), 22-27.

Kourie, C., 1998, 'Transformative symbolism in the New Testament', Myth and Symbol 3, 3-24.

Kourie, C., 2012, 'Scripture and mystical transformation', Vinayasadhana: Dharmaram Journal of Psycho-Spiritual Formation 3(1), 29-43.

Kourie, C., 2015, 'Weaving colourful threads: A tapestry of spirituality and mysticism', HTS Teologiese Studies/Theological Studies 71(1), 1-9. http://dx.doi.org/10.4102/ hts.v71i1.3023

Lam, J.E., 2012, 'The Canticle of spiritual direction: A transformative approach to the Song of Songs', viewed from http://uir.unisa.ac.za/handle/10500/8103

Lam, J.E., 2015, 'Reading the Song of Songs through a Spiritual Direction Lens', viewed from http://www.hts.org.za/index.php/HTS/article/viewFile/2959/pdf_1

Latourette, K.S., 1929, A history of Christian missions in China, Macmillan, New York.

McGinn, B., 2006, The essential writings of Christian Mysticism, Modern Library, New York.

McGinn, B., 2012, 'The Mystical tradition', in P. Tyler \& R. Woods (eds.), The Bloomsbury guide to Christian Spirituality, pp. 30-41, Bloomsbury Publishing, London.

Perrin, D.B., 2007, Studying Christian Spirituality, Routledge, New York.

Perrin, D.B., 2011, 'Mysticism', in A. Holder (ed.), The Blackwell Companion to Christian Spirituality, pp. 442-458, Wiley, West Sussex.

Pollock, J., [1962]/1996, Hudson and Maria, Christian Focus Publications, Ross-shire.

Reilly, M.C., 1978, Spirituality for mission, Orbis Books, Maryknoll, NY.

Schneiders, S., 2011, 'What is Christian Spirituality?', in A. Holder (ed.), The Blackwell Companion to Christian Spirituality, pp. 15-33, Wiley, West Sussex.

Taylor, H. \& Taylor, G., 1965, Biography of James Hudson Taylor, Moody Press, Chicago, IL.

Taylor, J.H., [1894]/2006, 'Union and communion', in J.P. Dorsey (ed.), The collected works of J. Hudson Taylor of the China Inland mission, pp. 61-109, Dust \& Ashes Publications, Spring Lake, MI.

Thompson, P., 1982, Each to her post: Six women of the China Inland mission, Hodder and Stoughton, London.

Waaijman, K., 2002, Spirituality. Forms, foundations, methods, Peeters, Leuven.

Wigram, C.E.M., 2007, The Bible and Mission in faith perspective: J. Hudson Taylor and the Early China Inland Mission, Uitgeverij Boekencentrum, Zoetermeer. 